\title{
Determinants of the quality of life amongst HIV clinic attendees in Malang, Indonesia
}

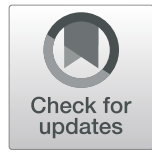

Sri Sunaringsih Ika Wardojo ${ }^{1,2}$, Ya-Li Huang ${ }^{1,3}$ and Kun-Yang Chuang ${ }^{1 *}$ (D)

\begin{abstract}
Background: As the number of people living with human immunodeficiency virus (HIV; PLHIV) in Indonesia has increased in recent years, more efforts have been expended to improve their health status. However, in a country where PLHIV are very much stigmatized, there has been little research concerning their quality of life (QoL). Hence, this study aimed to assess the QoL among PLHIV and its associated factors. Findings of this research can contribute to improving the health and wellbeing of PLHIV in Indonesia.

Methods: A cross-sectional survey with convenience sampling was conducted from June to September 2018, at four healthcare centers in Malang, Indonesia. PLHIV, aged 18 years or over, were asked if they would like to participate in this study when they came to a health center to receive services. To protect confidentiality, the healthcare staff at the clinics assisted with recruitment and face-to-face interviews with structured questionnaires. Measurements included sociodemographic, medication-related, social support, HIV-stigma, and QoL variables.

Results: In total, 634 PLHIV agreed to participate in this study. A multivariate linear regression analysis showed that being older, having a job, living in an urban area, having better access to healthcare services, adhering to medication, being in an antiretroviral therapy (ART) program for more than 1 year, experiencing a lower level of stigma, and receiving more social support were associated with a better QoL. The regression model had an adjusted $R^{2}$ of 0.21 .

Conclusions: Findings from this research have significant policy implications. Policies focused on reducing social stigma and promoting medication adherence will likely have a positive impact on the QoL of PLHIV. Increasing public awareness and acceptance of PLHIV in Indonesia remains challenging, but would likely have significant impacts. Furthermore, interventions should also focus on reducing disparities in QoL between PLHIV living in rural areas and those in urban areas.
\end{abstract}

Keywords: QoL, HIV, Stigma, ART adherence

\section{Background}

Indonesia, ranked 13th worldwide in the number of people living with human immunodeficiency virus (HIV; PLHIV), with an estimates of PLHIV in 2020 were 543, 075 [1], and the annual incident cases of HIV in Indonesia has also increased from 12,214 per year in 2013 to 50,282 per year in 2020 [1]. The first AIDS

\footnotetext{
* Correspondence: adinma@tmu.edu.tw

${ }^{1}$ School of Public Health, Taipei Medical University, Taipei, Taiwan

Full list of author information is available at the end of the article
}

national strategy was implemented in 1997 [2], with a focus on HIV/AIDS control through care and treatment support programs. In 2003, Indonesia Ministry of Health implemented a second AIDS national strategy which is still in effect in 2021, with its main focus being HIV prevention and treatment [3]. Antiretroviral Treatment (ART) is being fully subsidized and is provided at primary health care centers. This guidelines recommended immediate initiation of ART after HIV diagnosis regardless of the individual's clinical or immunological status [3]. Other programs such as needle exchange program

C The Author(s). 2021 Open Access This article is licensed under a Creative Commons Attribution 4.0 International License, which permits use, sharing, adaptation, distribution and reproduction in any medium or format, as long as you give appropriate credit to the original author(s) and the source, provide a link to the Creative Commons licence, and indicate if changes were made. The images or other third party material in this article are included in the article's Creative Commons licence, unless indicated otherwise in a credit line to the material. If material is not included in the article's Creative Commons licence and your intended use is not permitted by statutory regulation or exceeds the permitted use, you will need to obtain permission directly from the copyright holder. To view a copy of this licence, visit http://creativecommons.org/licenses/by/4.0/ The Creative Commons Public Domain Dedication waiver (http://creativecommons.org/publicdomain/zero/1.0/) applies to the data made available in this article, unless otherwise stated in a credit line to the data. 
and methadone maintenance treatment were implemented as well. As of September 2020, there were 1515 ART primary care centers nationwide [4].

In Indonesia, with the largest Muslim population in the world, communicating about sex and HIV are often considered taboo, and this leads to a low understanding of the symptoms and preventive measures of this disease [5]. Moreover, social stigmatization and discrimination against PLHIV still pose significant obstacles to prevention and treatment [6-8]. As such, previous studies [7, 8] reported that PLHIV have experienced rejection by healthcare workers, have been denied care because of their HIV status, and thus fear to disclose their status. Lack of family, peer, and community support also contributes to high loss of follow-up of ART medication [9]. All of these have negative impacts on the wellbeing of PLHIV. Quality of life (QoL) is an important component when evaluating the wellbeing of PLHIV, and despite the recent growth in numbers, little research has been conducted concerning the QoL among PLHIV. Moreover, as ART has been available as long-term regimen care for PLHIV, the QoL has become a significant indicator for evaluating the impacts of ART [10]. Hence, research on QoL among PLHIV will provide additional insights into challenges they face, and into how to improve their wellbeing.

Previous research, using the World Health Organization Quality of Life in the HIV-infected person instrument (WHOQOL-HIV-BREF) questionnaire [11], indicated that a higher QoL level was associated with being male [12, 13], being of a younger age [14], being employed [15, 16], and having a better financial status and a higher educational level [17-21]. Moreover, factors such as adherence to ART [22] and social support [23] were also associated with a higher level of QoL, while poor access to healthcare services [24] and stigmatization [16, 25] were associated with a lower QoL.

PLHIV in Indonesia face several challenges, such as high levels of community stigmatization and discrimination, and they were reported to have a lower level of QoL compared to those in other Asian countries [21, 26]. Hence, this study aimed to assess the QoL among PLHIV and whether sociodemographic, social support, stigmatization, or healthcare factors were associated with QoL. To improve the life and wellbeing of PLHIV in Indonesia, it is essential to understand factors associated with their QoL before appropriate interventions can be devised.

\section{Methods}

\section{Study design and participants}

A cross-sectional study with a convenience sampling method was conducted. Time and sample size concerns were the reasons for recruiting PLHIV from clinics.
PLHIV faces prejudice and negative consequences of social isolation and exclusion once identity is known. Surveys utilizing snowball sampling, or other form of random sampling, would require a long period of time to build up trust with participants, and may also have the problem of having a small sample size, as well. Study participants were recruited from four clinics (Puskesmas Dinoyo, Puskesmas Kendalsari, RST Dr. Soepraoen, and RS Islam Malang) which provide voluntary counseling and testing (VCT) and ART services in Malang, Indonesia. Malang was reported to have the secondhighest HIV+ prevalence rate in East Java Province [27].

To protect the confidentiality of PLHIV, healthcare staff at the clinics assisted with recruiting participants and data collection. Because participants were concerned with privacy and disclosure, and were less interested in meeting with outside researchers, they were more willing to participate in surveys if administered by clinic staff, with whom they have regular contact. Staff at the clinics received training from the researchers regarding the procedures of recruitment and data collection. From June to September 2018, PLHIV who came to the clinics to receive health services were asked if they would be willing to participate in this study. Only those aged over 18 years were recruited. Face-to-face interviews were then conducted with a structured questionnaire by the same healthcare staff. In total, 634 HIV patients agreed to participate in this study.

\section{Measurements}

Variables used in this study included QoL, social support, and stigma measures, as well as sociodemographic characteristics and medication-related variables. QoL was measured using the WHOQOL-HIV BREF questionnaire. The WHOQOL-HIV BREF consists of 31 items rated on a 5-point Likert scale, which cover six domains of physical, psychological, level of independence, social relationship, environment, and spirituality. A total score is computed, with a higher score indicating a better QoL $[28,29]$. This instrument was developed and validated in several countries [17, 30-32], including Indonesia $[26,33]$. The reliability of this instrument was high, with $\alpha=0.86$ [33].

Social support was measured using the Multidimensional Scale of Perceived Social Support (MSPSS) [34]. It covers support in time of need from friends, family, and significant others. The MSPSS consists of 12 items, such as "I can talk about my problems with my family" and "My friends really try to help me", that ask respondents to rate their perceived level of support on a Likert scale ranging from 1 "very strongly disagree" to 7 "very strongly agree", with a higher score indicating greater social support. A previous study reported that the Indonesian version of the MSPSS had a reliability of 0.81 [35]. 
The HIV stigma scale by Reinius et al. [36], a version modified from Berger et al. [37], was used to measure stigma. It consists of 12 items with a Likert scale, covering four areas of stigma: personalized, disclosure, public attitudes, and self-image. Each subscale consists of three items, and the response to each item ranges from 1 "strongly agree" to 4 "strongly disagree". The total score in each subscale is calculated by adding up the raw values of the items, and a higher score reflects a higher level of HIV-related stigmatization. Sample items include "People I care about stopped calling after learning I have HIV" and "I have been hurt by how people reacted to learning I have HIV". It previously demonstrated high reliability and validity among PLHIV, with reliability for the entire scale of 0.83 [38].

Sociodemographic characteristics included age, sex (male or female), marital status (unmarried, married, divorced, or widowed), educational level (primary education, secondary education, or tertiary education), working status (yes or no), household monthly income ( $<$ US $\$ 108$, US $\$ 108 \sim 180$, US $\$ 180 \sim 250$, and $>$ US $\$ 250$, with the average exchange rate in 2018 of US\$1.00 Rp14,000), and living area (urban or rural). Accessibility to health services was assessed with the question "Thinking of access of healthcare services in the past 12 months, how accessible was it for you to obtain the healthcare services you needed?" [39]. The response categories were 'very difficult', 'difficult', 'average', 'easy', and 'very easy'. This question did not specifically refer to time, cost, or other barriers to health services, but mainly tried to assess the subjective feeling of how difficult it was to obtain needed services. In the data analysis, "very difficult" and "difficult" were grouped together to represent "difficult", "average' and 'easy' were merged together to represent "easy', while "very easy" stands by itself.

Medication-related variables included the cluster difference 4 (CD4) count $(<200,200 \sim 500$, or $>500$ cells/ $\mathrm{mm}^{3}$ ), length of ART ( $<2$ or $\geq 2$ years), length of diagnosis with HIV counted in years since the first diagnosis of HIV, and adherence to medication (yes or no). Adherence to medication was measured using the AIDS (acquired immunodeficiency syndrome) Clinical Trial Group (ACTG) questionnaire [40-42], which assesses the number of missed pills (at least one dose) in the past 2 weeks, as being non-adherent to ART with a yes/no answer.

\section{Statistical analysis}

Descriptive univariate statistics consisted of the frequency and percentage for categorical variables, and the mean and standard deviation (SD) for continuous variables. A $t$-test, analysis of variance (ANOVA), and Pearson's correlation, depending on the type of variable, were used to assess the relationship between two variables. A multivariate linear regression was used to assess relationships between predictors and QoL. The level of statistical significance was set to $p<0.05$. All analyses were performed using SPSS vers. 20 (SPSS, Chicago, IL, USA).

\section{Ethical considerations}

Ethical clearance for this study was obtained and approved by the University of Muhammadiyah Malang Ethics Committee of Indonesia (no E.5.1/066/KEPK$\mathrm{UMM} / \mathrm{II} / 2018$ ). As all participants were adults, the risks of participation in this study were explained to participants before they completed the written consent form.

\section{Results}

Table 1 shows the basic demographic characteristics and QoL scores. In total, 634 PLHIV participated in this study. Nearly $40 \%$ of them were younger than 30 years, and $77 \%$ of them were males. As to medication variables, $70 \%$ of participants had not missed their medication in the past 2 weeks, and $52.5 \%$ had been on ART for more than 2 years. Higher QoL scores were found among participants aged $61 \sim 65$ and $51 \sim 55$ years. Factors that may be associated with higher QoL scores were being married, working, living in an urban area, having access to health care, adhering to medication, and being on ART for more than 2 years.

Table 2 shows correlations of social support, stigma subscales, and length of the diagnosis with the QoL. Results indicated that the QoL had a positive and significant correlation with social support, and had negative and significant correlations with all stigma subscales (personalized, disclosure, and self-image). Correlations ranged $0.08 \sim 0.25$. The correlation between the length of time with an HIV diagnosis and the QoL was not statistically significant.

Table 3 shows results of the multivariate linear regression. After controlling for other variables, age, working status, living area, access to healthcare, medication, length of ART, personalized stigma, disclosure stigma, self-image stigma, and social support were significantly associated with the QoL. The regression model had an adjusted $R^{2}$ of 0.21 .

\section{Discussion}

Consistent with some previous research, older PLHIV had a higher QoL score. Some previous research speculated that older PLHIV had a higher level of acceptance of having been diagnosed with HIV [42, 43], were more likely turn to their religious faith, and were less likely to complain about their limitations [17]. On the other hand, other research indicated that younger PLHIV had a better QoL because of their better physical health [30]. 
Table 1 Basic characteristics of participants $(N=634)$

\begin{tabular}{|c|c|c|c|}
\hline & \multirow[t]{2}{*}{$n$} & \multirow[t]{2}{*}{$\%$} & \multirow{2}{*}{$\begin{array}{l}\text { QoL } \\
\text { Mean (SD) }\end{array}$} \\
\hline & & & \\
\hline \multicolumn{4}{|l|}{ Age (years)* } \\
\hline$<20$ & 40 & 6.3 & $84.81(7.69)$ \\
\hline $21-25$ & 82 & 12.9 & $82.02(7.49)$ \\
\hline $26-30$ & 130 & 20.5 & $84.38(6.93)$ \\
\hline $31-35$ & 108 & 17.0 & $86.72(8.16)$ \\
\hline $36-40$ & 70 & 11.0 & $84.94(6.51)$ \\
\hline $41-45$ & 82 & 12.9 & $84.97(6.69)$ \\
\hline $46-50$ & 57 & 9.0 & $85.57(9.60)$ \\
\hline $51-55$ & 32 & 5.0 & $87.54(6.20)$ \\
\hline $56-60$ & 26 & 4.1 & $84.98(7.23)$ \\
\hline $61+$ & 7 & 1.1 & $87.90(4.03)$ \\
\hline \multicolumn{4}{|l|}{ Sex } \\
\hline Male & 488 & 77.0 & $84.78(7.76)$ \\
\hline Female & 146 & 23.0 & $85.60(6.68)$ \\
\hline \multicolumn{4}{|l|}{ Educational level } \\
\hline Primary education & 182 & 28.7 & $85.01(6.66)$ \\
\hline Secondary education & 238 & 37.5 & $84.61(7.18)$ \\
\hline Tertiary education & 214 & 33.8 & $85.33(8.54)$ \\
\hline \multicolumn{4}{|l|}{ Marital status* } \\
\hline Unmarried & 282 & 44.5 & $83.96(7.17)$ \\
\hline Married & 230 & 36.3 & $86.01(8.24)$ \\
\hline Divorced & 90 & 14.2 & $84.83(5.17)$ \\
\hline Widowed & 32 & 5.0 & $86.83(9.60)$ \\
\hline \multicolumn{4}{|l|}{ Household income } \\
\hline$<$ US\$ 108 & 144 & 22.7 & $84.54(7.78)$ \\
\hline US\$108 US\$ 180 & 258 & 40.7 & $84.86(7.90)$ \\
\hline US\$ $180 \sim$ US\$ 250 & 142 & 22.4 & $84.76(6.28)$ \\
\hline > US\$ 250 & 90 & 14.2 & $86.29(7.79)$ \\
\hline \multicolumn{4}{|l|}{ Working* } \\
\hline No & 83 & 13.1 & $82.73(9.23)$ \\
\hline Yes & 551 & 86.9 & $85.31(7.18)$ \\
\hline \multicolumn{4}{|l|}{ Living area** } \\
\hline Urban & 291 & 45.9 & $86.01(7.69)$ \\
\hline Rural & 343 & 54.1 & $84.09(7.28)$ \\
\hline \multicolumn{4}{|c|}{ Accessibility for obtaining healthcare services** } \\
\hline Difficult & 160 & 25.2 & $84.28(6.09)$ \\
\hline Easy & 314 & 49.5 & $84.37(7.60)$ \\
\hline Very easy & 160 & 25.2 & $86.85(8.36)$ \\
\hline \multicolumn{4}{|c|}{ Adherence to medication*** } \\
\hline Yes & 446 & 70.3 & $85.71(7.54)$ \\
\hline No & 188 & 29.7 & $83.22(7.21)$ \\
\hline \multicolumn{4}{|l|}{ CD4 count (cells/mm³) } \\
\hline$<200$ & 210 & 33.1 & $84.31(7.77)$ \\
\hline
\end{tabular}


Table 1 Basic characteristics of participants $(N=634)$ (Continued)

\begin{tabular}{llll}
\hline & $n$ & $\%$ & QoL \\
& & & Mean (SD) \\
\hline $200 \sim 500$ & 335 & 52.8 & $85.34(6.94)$ \\
$>500$ & 89 & 14.1 & $85.11(8.92)$ \\
Length of ART (years) & & \\
$\leq 1.99$ & 301 & 47.5 & $83.77(7.55)$ \\
$2 \sim 14.1$ & 333 & 52.5 & $86.05(7.35)$ \\
\hline
\end{tabular}

* $p<0.05$;** $p<0.01$;** $p<0.001$

QoL quality of life; $S D$ standard deviation; $C D 4$ cluster difference 4; $A R T$ adherence to antiretroviral therapy

The average exchange rate in 2018 was US\$1.00 $\approx \mathrm{Rp} 14,000$

In this research, after controlling for physical health, older PLHIV appeared to have a better QoL. Hence, it is likely that with improvements in care and therapy, older PLHIV would show improvements in QoL as well. In this research, employment had a positive influence on QoL. Such a relationship between employment and QoL was also identified in previous studies $[15,16]$. Employment could provide additional financial resources and also improve social networking and social support [16]. All these factors could contribute to a higher QoL. However, to be employed, a person probably has to be healthier, and hence, already with a higher QoL. Rueda et.al [23] stated that the employment status had a stronger relationship with physical health than mental health. Future studies could use a longitudinal study design to assess the causal relationship between employment and QoL.

In this study, after controlling for other factors, personalized stigma, disclosure stigma, and self-image stigma were significantly associated with a lower QoL. Stigmatization and discrimination frequently prevent PLHIV from acquiring needed services and support. Misunderstanding of HIV/AIDS has probably led to stigmas and public fear. A recent study indicated that as high as 55\% of the general public have a poor understanding of HIV/AIDS and tend to associate HIV/AIDS with female sex workers, men who have sex with men, and intravenous drug users, all of whom are subject to intense social stigmatization in Indonesia [44]. Such stigmatizing attitudes were also generally present among healthcare providers and varied by religious preferences [7]. Indonesia, the most populous Muslim-majority country, where cultural identity and self-awareness are based on religious faith [45], faces conflicting values regarding HIV/AIDS care and prevention. It is the government's responsibility to provide needed care to PLHIV, educate the general public about scientific facts concerning HIV, and advocate protective behaviors, such as the use of condoms. Yet, efforts of public campaigns or health education within schools are frequently met with objections and resistance from conservative groups. Determining how to provide needed care, promote HIV prevention, and appease religious groups continues to be a challenge for the Health Ministry in Indonesia. Despite several public campaigns aimed at reducing the stigma associated with HIV/AIDS, their effectiveness has not been evaluated.

Access to healthcare services and medication adherence significantly contribute to the QoL among PLHIV, as indicated in this research and in other previous research $[46,47]$. Similarly, those who had remained in an ART program for more than 1 year and those who had not missed their medications also tended to have a better QoL. In Indonesia, voluntary counseling and testing

Table 2 Correlation coefficients among social support, stigma, length of diagnosis and quality of life (QoL)

\begin{tabular}{|c|c|c|c|c|c|c|c|}
\hline & QoL & Social support & $\begin{array}{l}\text { Stigma: } \\
\text { Personalized }\end{array}$ & $\begin{array}{l}\text { Stigma: } \\
\text { disclosure }\end{array}$ & $\begin{array}{l}\text { Stigma: } \\
\text { public attitudes }\end{array}$ & $\begin{array}{l}\text { Stigma: } \\
\text { self-image }\end{array}$ & $\begin{array}{l}\text { Length of diagnosis } \\
\text { with HIV }\end{array}$ \\
\hline QoL & 1 & & & & & & \\
\hline Social support & $0.24^{* *}$ & 1 & & & & & \\
\hline Stigma: personalized & $-0.08^{*}$ & 0.22 & 1 & & & & \\
\hline Stigma: disclosure & $-0.14^{* *}$ & -0.03 & 0.002 & 1 & & & \\
\hline Stigma: public attitudes & $-0.10^{* *}$ & -0.29 & $-0.25^{* *}$ & $0.15^{* *}$ & 1 & & \\
\hline Stigma: self-image & $-0.25^{* *}$ & 0.01 & $-0.07^{*}$ & $0.09^{*}$ & $0.13^{* *}$ & 1 & \\
\hline Length of diagnosis with HIV & 0.06 & $-0.08^{*}$ & 0.01 & $-0.09^{*}$ & -0.03 & -0.04 & 1 \\
\hline
\end{tabular}

*p $<0.05$;* $p<0.01$

HIV human immunodeficiency virus 
Table 3 Multivariate linear regression of the quality of life (QoL)

\begin{tabular}{|c|c|c|c|}
\hline & \multicolumn{2}{|c|}{ Unstandardized coefficients } & \multirow{2}{*}{$\begin{array}{l}\text { Standardized coefficients } \\
\beta\end{array}$} \\
\hline & B & SE & \\
\hline \multicolumn{4}{|c|}{ Sociodemographic characteristics } \\
\hline Age & 0.27 & 0.13 & $0.08^{*}$ \\
\hline Sex & 0.75 & 0.65 & 0.04 \\
\hline Educational level & 0.61 & 0.35 & 0.06 \\
\hline \multicolumn{4}{|l|}{ Marital Status (ref: Unmarried) } \\
\hline a. married & 1.03 & 0.64 & 0.06 \\
\hline b. divorced & -0.05 & 0.86 & -0.003 \\
\hline c. widowed & 0.58 & 1.30 & 0.01 \\
\hline Household income & -0.00 & 0.29 & 0.00 \\
\hline Working (ref: No) & 1.70 & 0.83 & $0.07^{*}$ \\
\hline Living area (ref: Urban) & -1.74 & 0.54 & $-0.11^{* *}$ \\
\hline \multicolumn{4}{|c|}{ Accessibility of health care (ref: Difficult) } \\
\hline a. easy & 0.92 & 0.38 & $0.08^{* *}$ \\
\hline b. very easy & 0.94 & 0.36 & $0.04^{*}$ \\
\hline \multicolumn{4}{|l|}{ Medication variables } \\
\hline Adherence to medication & 1.99 & 0.61 & $0.12^{* *}$ \\
\hline CD4 count & -0.17 & 0.41 & -0.01 \\
\hline Length of ART (ref: $\leq 1.99$ ) & 1.95 & 0.74 & $0.13^{* *}$ \\
\hline Length of diagnosis with HIV & -0.13 & 0.14 & -0.05 \\
\hline \multicolumn{4}{|l|}{ Stigma subscales } \\
\hline Stigma: personalized & -0.61 & 0.18 & $-0.13^{* *}$ \\
\hline Stigma: disclosure & -0.34 & 0.17 & $-0.07^{*}$ \\
\hline Stigma: public attitudes & -0.14 & 0.16 & -0.03 \\
\hline Stigma: self-image & -1.05 & 0.19 & $-0.19^{* * *}$ \\
\hline Social support & 0.42 & 0.05 & $0.29^{* * *}$ \\
\hline
\end{tabular}

Adjusted $R^{2}=0.21 ;{ }^{*} p<0.05 ;{ }^{* *} p<0.01 ;{ }^{* * *} p<0.001$

$A R T$ adherence to antiretroviral therapy; CD4 cluster difference 4; HIV human immunodeficiency virus

(VCT) and ART services can be obtained at primary health centers. VCT and ART service programs were first provided in 2005 and 2003, respectively. Both services have been provided free of charge since their initiation. In 2015, there were 2221 primary health centers that provided VCT and ART services. About $48 \%$ of primary care centers that provide VCT and ART services are located in Jakarta, East Java, and Papua Provinces where $45 \%$ of PLHIV are located.

Despite widespread access, the Ministry of Health reported only $41 \%$ of people with advanced HIV infection had received ART as of August 2018 [48]. Determining how to increase utilization rates of ART services among PLHIV has become a challenge for health officials. It was speculated that possible reasons for not receiving ART services include side effects, religious beliefs, stigmatization, difficulties incorporating medication moments in daily activities, a high pill burden, and difficulties accessing services [7, 8]. Since most ART service centers are located in urban areas, the additional costs of transportation and traveling times may deter some PLHIV living in rural areas from using those services. Improving access to services in rural areas would likely improve utilization rates. Since traditional values still discriminate against PLHIV, it is essential that their personal identity and privacy be protected throughout the process of receiving ART services. A willingness to use HIV-related services will hinge upon how well personal information is protected and how much PLHIV trust public systems to protect their identities. Thus far, no research has evaluated the level of trust among PLHIV regarding privacy protection. Moreover, evaluations regarding the protocols of service delivery, especially with regard to identity protection, should be conducted to increase the trust of PLHIV in public systems.

Although this study has contributed to understanding factors associated with the QoL among PLHIV in Indonesia, there are several limitations. First, only a 
limited number of variables were covered in this study, and other important factors related to QoL, particularly risky behaviors, the viral load, and the stage of infection, were not examined. Second, the cross-sectional nature of the analysis limited us from drawing causal inferences between explanatory factors and the QoL. And third, QoL might have been over-estimated, since participants were recruited only from ART clinics, and data were collected by clinic staffs. PLHIV receiving ART services were likely to have a higher level of QoL than those not receiving ART services. Although the use of clinic staffs to collect data may increase the willingness of PLHIV to participate in this study, it may also introduce possible bias in combination with the convenience sampling approach. Thus, our findings may have overestimated the level of wellbeing among PLHIV. Generalizing results to other areas in Indonesia should done with careful consideration of these issues. Despite these limitations, the study provides evidence of the importance of considering stigma subscales, social support, sociodemographic characteristics, and medication variables, in both research and practice, to promote the QoL among HIV patients in Indonesia.

\section{Conclusions}

This study found that PLHIV of an older age, with a job, who live in an urban area, with better access to healthcare services, who are adherent to their medication, who are receiving ART treatment for $>1$ year, and with better social support were positively associated with a better QoL. However, personalized stigma, disclosure stigma, and self-image stigma were associated with a lower QoL. Thus, promoting medication adherence for PLHIV and enhancing public awareness about HIV/AIDS in order to reduce stigmas and show support might positively impart a better QoL among PLHIV in Indonesia.

\footnotetext{
Abbreviations

ACTG: AIDS clinical trial group; AIDS: Acquired immunodeficiency syndrome; ANOVA: Analysis of variance; ART: Antiretroviral therapy; CD4: Cluster of differentiation 4; HIV: Human immunodeficiency virus;

MSPS: Multidimensional scale of perceived support; PLHIV: People living with HIV; QoL: Quality of life; SD: Standard deviation; VCT: Voluntary counseling and testing; WHOQOL-HIV BREF: World health organization quality of life in the HIV-infected person
}

\section{Acknowledgements}

We acknowledge the work and dedication of Puskesmas Dinoyo, Puskesmas Kendalsari, Dr. RST Soepraoen, and RS Islam Malang, and all participants who generously participated in this study.

\section{Authors' contributions}

SSIW and KYC designed the study. SSIW carried out data collection, data analysis, and data interpretation, and drafted the manuscript. YLH and KYC assisted in the literature review and supervised all critical data analysis and manuscript preparation. All authors read and approved the final manuscript.

\section{Funding}

This study received no funding.
Availability of data and materials

Data from this study are available from the corresponding author upon reasonable request.

\section{Declarations}

\section{Ethics approval and consent to participate}

Ethics approval was obtained from the University of Muhammadiyah Malang Ethics Committee of Indonesia (no: E.5.1/066/KEPK-UMM/II/2018). Also, all participants provided written informed consent before data collection began.

\section{Consent for publication}

Not applicable.

\section{Competing interests}

The authors declare that they have no competing interests.

\section{Author details}

${ }^{1}$ School of Public Health, Taipei Medical University, Taipei, Taiwan. ${ }^{2}$ Faculty of Health Science, University of Muhammadiyah, Malang, Indonesia.

${ }^{3}$ Department of Public Health, School of Medicine, College of Medicine,

Taipei Medical Univeristy, Taipei, Taiwan.

Received: 29 May 2020 Accepted: 18 June 2021

Published online: 30 June 2021

\section{References}

1. Kemenkes RI. Infodatin HIV AIDS. Kesehatan. 2020;1-8. http://www.depkes. $\mathrm{go.id} /$ resources/download/pusdatin/infodatin/Infodatin AIDS.pdf.

2. Demartoto A, Murti B, Zunariyah S. HIV/AIDS treatment funding system to support the people affected by HIV/AIDS in Surakarta, Indonesia. SAHARA-J J Soc Asp HIV/AIDS. 2021;18(1):1-16. https://doi.org/10.1080/17290376.202 0.1858946.

3. Direktur Jenderal P2P Kementrian Kesehatan RI. Program Pengendalian HIV AIDS dan PIMS Fasilitas Kesehatan Tingkat Pertama. 2017;:1-109.

4. Direktur Jenderal P2P Kementrian Kesehatan RI. Laporan Perkembangan HIV AIDS \& Penyakit Menular Seksual. Jakarta Indonesia; 2020. https://siha. kemkes.go.id/portal/files_upload/Laporan_Perkembangan_HIV_AIDS_dan_ PIMS_Triwulan_III_Tahun_2020.pdf.

5. Januraga PP, Mooney-Somers J, Ward PR. Newcomers in a hazardous environment: a qualitative inquiry into sex worker vulnerability to HIV in Bali, Indonesia. BMC Public Health. 2014;14(1):832. https://doi.org/10.1186/14 71-2458-14-832

6. Riono P, Challacombe SJ. HIV in Indonesia and in neighbouring countries and its social impact. Oral Dis. 2020;26(S1):28-33. https://doi.org/10.1111/ odi.13560.

7. Waluyo A, Culbert GJ, Levy J, Norr KF. Understanding HIV-related stigma among Indonesian nurses. J Assoc Nurses AIDS Care. 2015;26(1):69-80. https://doi.org/10.1016/j.jana.2014.03.001.

8. Supriyadi MT, Yuliana F. The disjunction between policy and practice: HIV discrimination in health care and employment in Indonesia. AIDS Care. 2005;17(SUPPL. 2):37-41.

9. Wisaksana R, Alisjahbana B, van Crevel R, Kesumah N, Sudjana P, Sumantri R. Challenges in delivering HIV-care in Indonesia: experience from a referral hospital. Acta Med Indones. 2009;41(Suppl 1):45-51.

10. Basavaraj KH, Navya MA, Rashmi R. Quality of life in HIV/AIDS. Indian J Sex Transm Dis AIDS. 2010;31(2):75-80. https://doi.org/10.4103/0253-7184.74971.

11. World Health Organization. Whogol-Hiv Bref Mental Health : Evidence and Research Department of Mental Health World Health Organization.Geneva; 2002. https://www.who.int/mental_health/publications/whogol_hiv_bref. pdf.

12. Briongos Fiquero LS, Bachiller Luque P, Palacios Martín T, González Sagrado M, Eiros Bouza JM. Assessment of factors influencing health-related quality of life in HIV-infected patients. HIV Med. 2011;12(1):22-30. https://doi.org/1 0.1111/j.1468-1293.2010.00844.x.

13. Protopopescu C, Raffi F, Roux P, Reynes J, Dellamonica P, Spire B, et al. Factors associated with non-adherence to long-term highly active antiretroviral therapy: a 10 year follow-up analysis with correction for the bias induced by missing data. J Antimicrob Chemother. 2009;64(3):599-606. https://doi.org/10.1093/jac/dkp232. 
14. Gibson K, Rueda S, Rourke SB, Bekele T, Gardner S, Fenta H, et al. Mastery and coping moderate the negative effect of acute and chronic stressors on mental health-related quality of life in HIV. AIDS Patient Care STDs. 2011; 25(6):371-81. https://doi.org/10.1089/apc.2010.0165.

15. George S, Bergin C, Clarke S, Courtney G, Codd MB. Health-related quality of life and associated factors in people with HIV: an Irish cohort study. Health Qual Life Outcomes. 2016;14(1):1-12. https://doi.org/10.1186/s12955-016-051 7-4.

16. Mekuria LA, Sprangers MAG, Prins JM, Yalew AW, Nieuwkerk PT. Healthrelated quality of life of HIV-infected adults receiving combination antiretroviral therapy in Addis Ababa. AIDS Care. 2015;27(8):934-45. https:// doi.org/10.1080/09540121.2015.1020748.

17. Nobre N, Pereira M, Roine RP, Sintonen H, Sutinen J. Factors associated with the quality of life of people living with HIV in Finland. AIDS Care. 2017;29(8): 1074-8. https://doi.org/10.1080/09540121.2017.1281879.

18. Monteiro F, Canavarro MC, Pereira M. Factors associated with quality of life in middle-aged and older patients living with HIV. AIDS Care. 2016; 28(March):92-8.

19. Passos SMK, Souza LD de M. An evaluation of quality of life and its determinants among people living with HIV/AIDS from southern Brazil. Cad Saude Publica. 2015;31(4):800-14. https://doi.org/10.1590/0102-311 X00000514.

20. Ferlatte $\mathrm{O}$, Salway T, Oliffe JL, Trussler T. Stigma and suicide among gay and bisexual men living with HIV. AIDS Care. 2017;29(11):1346-50. https://doi. org/10.1080/09540121.2017.1290762.

21. Koirala S, Deuba K, Nampaisan O, Marrone G, Ekström AM, Satti A, et al. Facilitators and barriers for retention in HIV care between testing and treatment in Asia- a study in Bangladesh, Indonesia, Lao, Nepal, Pakistan, Philippines, and Vietnam. PLoS One. 2017;12:1-20.

22. Geocze L, Mucci S, de Marco MA, Nogueira-Martins LA, de Albuquerque Citero V. Quality of life and adherence to HAART in HIV-infected patients. Rev Saude Publica. 2010;44(4):743-9. https://doi.org/10.1590/S0034-8910201 0000400019

23. Rueda S, Raboud J, Mustard C, Bayoumi A, Lavis JN, Rourke SB. Employment status is associated with both physical and mental health quality of life in people living with HIV. AIDS Care. 2011;23(4):435-43. https://doi.org/10.1 080/09540121.2010.507952.

24. O'Brien N, Greene S, Carter A, Lewis J, Nicholson V, Kwaramba G, et al. Envisioning women-centered HIV care: perspectives from women living with HIV in Canada. Womens Heal Issues. 2017;27(6):721-30. https://doi. org/10.1016/j.whi.2017.08.001

25. Herrmann S, McKinnon E, Hyland NB, Lalanne C, Mallal S, Nolan D, et al. HIVrelated stigma and physical symptoms have a persistent influence on health-related quality of life in Australians with HIV infection. Health Qual Life Outcomes. 2013;11:56. http://www.hqlo.com/content/11/1/56\%5C nhttp://ovidsp.ovid.com/ovidweb.cgi?T=JS\&PAGE=reference\&D= emed11\&NEWS=N\&AN=2013238859. https://doi.org/10.1186/1477-7525-1156.

26. Lindayani L, Chen YC, Der Wang J, Ko NY. Complex problems, care demands, and quality of life among people living with HIV in the antiretroviral era in Indonesia. J Assoc Nurses AIDS Care. 2018;29(2):300-9. https://doi.org/10.1016/j.jana.2017.10.002.

27. Health Department of Malang. Annual Progress Report. Annu Prog Rep. 2019. https://dinkes.malangkota.go.id/wp-content/uploads/sites/104/2019/ 09/LAKIP-2018.pdf.

28. Lindayani L, Ibrahim K, Der Wang J, Ko NY. Independent and synergistic effects of self- and public stigmas on quality of life of HIV-infected persons. AIDS Care. 2018;30(6):706-13. https://doi.org/10.1080/09540121.2017.1396282.

29. Garrido-Hernansaiz H, Heylen E, Bharat S, Ramakrishna J, Ekstrand ML. Stigmas, symptom severity and perceived social support predict quality of life for PLHIV in urban Indian context. Health Qual Life Outcomes. 2016; 14(1):152. https://doi.org/10.1186/s12955-016-0556-x.

30. Canavarro MC, Pereira M. AIDS care : psychological and socio-medical aspects of AIDS / HIV factor structure and psychometric properties of the European Portuguese version of a questionnaire to assess quality of life in HIV-infected adults : the. AIDS Care 2012;24June 2012:799-807. https://www.tandfonline. com/doi/abs/https:/doi.org/10.1080/09540121.2011.630362.

31. Hsiung PC, Fang CT, Wu CH, Sheng WH, Chen SC, Der Wang J, et al. Validation of the WHOQOL-HIV BREF among HIV-infected patients in Taiwan. AIDS Care. 2011;23(8):1035-42. https://doi.org/10.1080/09540121.201 0.543881 .
32. Saddki N, Noor MM, Norbanee TH, Rusli MA, Norzila Z, Zaharah S, et al. Validity and reliability of the Malay version of WHOQOL-HIV BREF in patients with HIV infection. AIDS Care. 2009;21(10):1271-8. https://doi.org/10.1080/ 09540120902803216.

33. Pujasari H, Levy J, Culbert G, Steffen A, Carley D, Kapella M. Sleep disturbance, associated symptoms, and quality of life in adults living with HIV in Jakarta, Indonesia. AIDS Care. 2021;33(1):39-46. https://doi.org/10.1 080/09540121.2020.1748868

34. Zimet GD, Dahlem NW, Zimet SG, Gordon K, Farley GK. The multidimensional scale of perceived social support the multidimensional scale of perceived social support. J Pers Assess. 2010;52:37-41.

35. Laksmita OD, Chung M-H, Liao Y-M, Chang P-C. Multidimensional scale of perceived social support in Indonesian adolescent disaster survivors: a psychometric evaluation. PLoS One. 2020;15(3):e0229958. https://doi.org/1 0.1371/journal.pone.0229958

36. Reinius $M$, Wettergren $L$, Wiklander $M$, Svedhem V, Ekström AM, Eriksson LE. Development of a 12-item short version of the HIV stigma scale. Health Qual Life Outcomes. 2017;15:1-9.

37. Berger BE, Ferrans CE, Lashley R. Measuring stigma in people with HIV: psychometric assessment of the HIV stigma scale. Res Nurs Health 2001;24 518-529. https://onlinelibrary.wiley.com/doi/abs/https://doi.org/10.1002/ Nur.10011, 6.

38. Luz PM, Torres TS, Almeida-Brasil CC, Marins LMS, Bezerra DRB, Veloso VG, et al. Translation and validation of the short HIV stigma scale in Brazilian Portuguese. Health Qual Life Outcomes. 2020;18:1-12.

39. European Patient Forum. Access to healthcare EPF's survey - final report. 2016::1-57.

40. Abdulrahman SA, Rampal L, Ibrahim F, Radhakrishnan AP, Shahar HK, Othman N. Mobile phone reminders and peer counseling improve adherence and treatment outcomes of patients on ART in Malaysia: a randomized clinical trial. PLoS One. 2017;12:1-16.

41. Amberbir A, Woldemichael K, Getachew S, Girma B, Deribe K. Predictors of adherence to antiretroviral therapy among HIV-infected persons: a prospective study in Southwest Ethiopia. BMC Public Health. 2008;8:1-9.

42. Catalan J, Tuffrey $V$, Ridge $D$, Rosenfeld D. What influences quality of life in older people living with HIV? AIDS Res Ther. 2017;14:1-10.

43. Owen G, Catalan J. "We never expected this to happen": narratives of ageing with HIV among gay men living in London, UK. Cult Heal Sex. 2012; 14(1):59-72. https://doi.org/10.1080/13691058.2011.621449.

44. Mahendradhata Y, Ahmad RA, Lefèvre P, Boelaert M, Van Der Stuyft P. Barriers for introducing HIV testing among tuberculosis patients in Jogjakarta, Indonesia: a qualitative study. BMC Public Health. 2008:8:1-10.

45. Grim BJ. Religious freedom: Good for what ails us? Rev Faith Int Aff. 2008;6: 3-7. https://doi.org/10.1080/15570274.2008.9523330.

46. García-Goñi M, Nuño-Solinís R, Orueta JF, Paolucci F. Is utilization of health services for HIV patients equal by socioeconomic status? Evidence from the Basque country. Int J Equity Health. 2015;14(1):1-10. https://doi.org/10.1186/ s12939-015-0215-6.

47. Tran BX. Quality of life outcomes of antiretroviral treatment for HIV/AIDS patients in Vietnam. PLoS One. 2012;7:1-8.

48. Ministry of Health. Annual Health Report. 2018. https://pusdatin.kemkes.go. id/article/view/19042200004/situasi-umum-hiv-aids-dan-tes-hiv.html.

\section{Publisher's Note}

Springer Nature remains neutral with regard to jurisdictional claims in published maps and institutional affiliations.

Ready to submit your research? Choose BMC and benefit from:

- fast, convenient online submission

- thorough peer review by experienced researchers in your field

- rapid publication on acceptance

- support for research data, including large and complex data types

- gold Open Access which fosters wider collaboration and increased citations

- maximum visibility for your research: over $100 \mathrm{M}$ website views per year

At $\mathrm{BMC}$, research is always in progress.

Learn more biomedcentral.com/submissions 